\title{
Supply-Side Practices and Constraints of the Kola Nut (Cola nitida (Vent) Schott. and Endl.) Value Chain in Ghana: A Descriptive Evidence
}

\author{
Frederick Amon-Armah ${ }^{D},{ }^{1}$ Solomon Sefa Oduro, ${ }^{1}$ Eric Kofi Doe $\mathbb{D},{ }^{2}$ Moses Asani, ${ }^{1}$ \\ Daniel Nyadanu, ${ }^{3}$ and Sampson Konlan ${ }^{4}$ \\ ${ }^{1}$ Social Science and Statistics Unit, Cocoa Research Institute of Ghana, P.O. Box 8, New-Tafo, Akyem, \\ Eastern Region, Ghana \\ ${ }^{2}$ Department of Geography and Resource Development, University of Ghana, Legon, Ghana \\ ${ }^{3}$ Plant Breeding Division, Cocoa Research Institute of Ghana, P.O. Box 8, New-Tafo, Akyem, Eastern Region, Accra, Ghana \\ ${ }^{4}$ Agronomy Division, Cocoa Research Institute of Ghana, P.O. Box 8, New-Tafo, Akyem, Eastern Region, Accra, Ghana
}

Correspondence should be addressed to Frederick Amon-Armah; famon-armah@hotmail.com

Received 22 March 2021; Accepted 22 May 2021; Published 30 May 2021

Academic Editor: Mathias N. Andersen

Copyright (C) 2021 Frederick Amon-Armah et al. This is an open access article distributed under the Creative Commons Attribution License, which permits unrestricted use, distribution, and reproduction in any medium, provided the original work is properly cited.

\begin{abstract}
The use of kola nut, including natural or alternative medicinal sources, has inevitably created an increased global market demand in excess of its production and provides great prospects for the growth of the kola nut industry in producing countries like Ghana. Nonetheless, there is a great dearth of information on Ghana's kola nut supply-side practices and constraints that can provide a basis for the development of the industry. This study fills the research gap by describing the practices and constraints of farmers, processors, and marketers of kola nut in Ghana. Using a survey methodology, results showed that nearly all (99.5\%) farmers interviewed had not received any extension training on agronomic practices. Low market price of nuts (61.5\%) and pests and diseases $(60.4 \%)$ were the most reported constraints to kola nut production. Chiefs among motivating factors for cultivating kola nut were alternative livelihood support (58\%). Some processors (28.6\%) who rinsed nuts after depulping used a solution of Akate Master (bifenthrin) and others (51.0\%) used fumigation tablets (aluminium phosphide) (91.0\%) for storing the nuts. However, these chemicals may be dangerous to the health of consumers in the long run. The low selling price of kola nuts was perceived to be the most $(74.8 \%)$ constraint to kola nut processing and marketing. Respondents noted that the red nuts were preferred for their durability during transportation and longer shelf life, while the white nuts were preferred for their taste. The results suggest the need for further agronomic, postharvest handling, preservation, and storage, as well as breeding research to provide recommendations to farmers and processors. To overcome some marketing challenges, there is a need for policy support to standardize pricing and grading systems for the mutual benefit of all the stakeholders.
\end{abstract}

\section{Introduction}

Kola (a member of the family Sterculiaceae) is a tropical tree crop with over 140 species [1] of which 50 species have been described in West Africa by Adebola [2], cited in Dadzie et al. [3]. C. acuminate Schott and Eudl. and C. nitida Schott and Eudl. are the most common species, but the latter which originated from Ghana and Sierra Leone [4] has gained much preference and become the more important of the two kola species [5]. Over $90 \%$ of the world's kola nut is produced in West Africa of which Nigeria contributes 50\%, Cameroon 27\%, Ivory Coast 16\%, and Ghana 8\% FAO [6].

The kola nut is of enormous medicinal benefits and great sociocultural importance in many West African cultures. In Ghana, the nuts are popular among the Muslim populations in the northern sections of the country and some parts of the transitional zones in the Brong Ahafo region [7]. Ghanaians and other Africans predominantly use kola nut as a sign of 
friendship and peace and in cultural ceremonies, such as part of dowry in marriage ceremonies, child naming, installation of Chiefs, and funerals. The nut is also used as a masticatory stimulant $[3,8,9]$.

The producer price of kola nut in Ghana increased steadily between the 1960s and 1990s, and this encouraged its cultivation by most farmers in the southern parts of the country leading to a dramatic increase in kola nut production [7]. About the same time, the government of Ghana greatly invested in promotional efforts to encourage kola nut production and marketing [7]. This increase in kola nut production prompted several agronomy and postharvest studies on kola nut by Brown and Afrifa [10]; Osei-Bonsu and Afrifa [11]; Osei-Bonsu et al. [12]; and Owusu-Manu and Bonku [13] to reduce field and postharvest losses to producers, processors, and exporters. Kola nut thus became one of three leading nontraditional agricultural export (NTAE) crops in Ghana including pineapples and yams [7]. However, in recent years, the volume of kola nut exports and its contribution to Ghana's total NTAE has dramatically dwindled [14] (Figure 1).

Resulting from an increase in the supply of the nuts in Ghana, the producer price for kola nut began to decline from about $\$ 1,700$ tonne-1 in 1992 to about $\$ 600$ tonne-1 in 2002 but started to rise in 2003 when production dwindled (Figure 2) [6]. In 2011, Ghana's kola producer price was $\$ 2,300$ tonne-1 (Figures 1 and 2) and this was more than twice that of Nigeria, the leading producer (\$730 tonne-1) [6]. However, the share of the nuts in Ghana's NTAE had been below $0.01 \%$ as a result of low production [14]. However, there is an opportunity for Ghana to enhance its revenue from kola nut exports if production increases.

The nut and its extracts have become popular in Europe and North America as a natural or alternative medicinal source and in the production of soft drinks, candies, beverages, animal feed formulation, liquid soap, and dyes $[3,8,9]$. In addition, according to Babatunde and Hamzat [15], the high nutritive quality of kola nut pod husk (as a byproduct) used for animal feed resulted in outstanding growth performance in broilers. The uses have inevitably created an increased global market demand in excess of its production $[8,16-18]$, which provides great prospects for the growth of the kola nut industry in Ghana.

Despite the history of the great contribution to the Ghanaian economy between the 1960s to the 1990s [7, 19] and the potential economic benefits to the country, there is a dearth of information on the Ghanaian kola nut industry which can be the basis for its development. Even though a few research outcomes exist, the research gap is still huge. For instance, Dadzie et al. [3] recommended propagation techniques that result in the early bearing of the kola nuts. Also, Asamoah et al. [20] reported from a field survey that about $88 \%$ of chemicals that were used in the processing of kola nuts by farmers and processors were toxic to human health. Lowor [21] then investigated the storage and processing of kola nut to preserve quality while increasing its shelf life and recommended that kola nut could be sun-dried on wooden trays with raffia palm-based mat, milled, and stored in sealed bags over a period of twelve months without

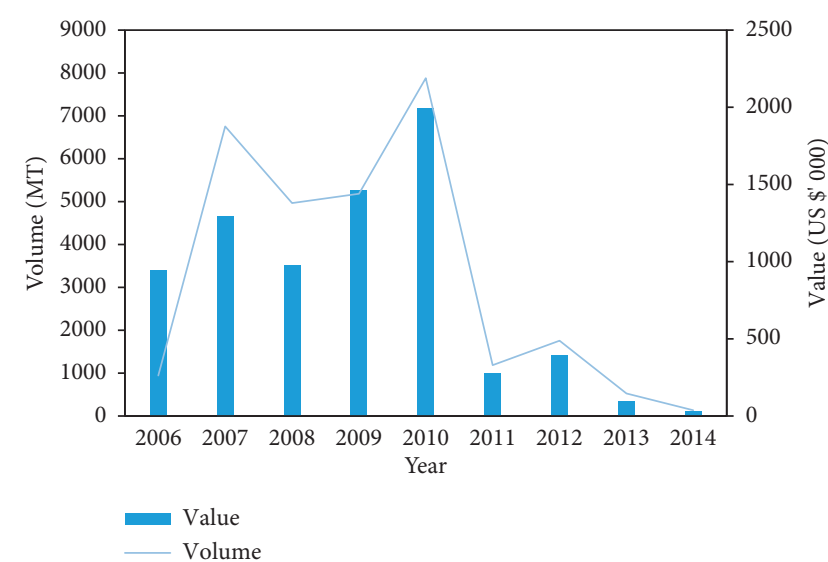

Figure 1: Volume and value of kola nut exports in Ghana. Source: Ministry of Food and Agriculture, 2015.

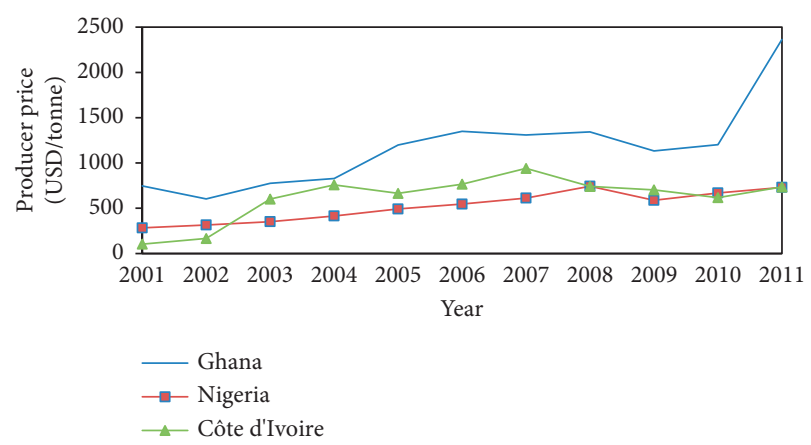

FIgUre 2: Comparison of kola nuts producer price (USD/tonne) between Ghana and two major world producers (2001 to 2011). Source: FAO (Food and Agricultural Organisation) [6].

compromising the requirements for industrial processing. However, it is unknown if producers and processors are aware of these techniques.

Except for studies by Asamoah et al. [20] on practices of kola nut processors, no study has assessed the supply-side agronomic, and postharvest practices, as well as constraints in Ghana. Many studies describe kola nut supply-side agronomic practices and constraints of Nigeria but there is pausity of such studies in Ghana. This study fills this research gap for the Ghanaian supply-side with the aim of exploring and describing the current practices and constraints of farmers, processors, and marketers in the industry. This information is important for research to enhance the development of technologies adoptable by the farmers and processors [8]. It will also inform policymakers on the state of the Ghanaian kola nut industry and form the base for policy initiatives and interventions targeted at reviving the industry.

\section{Methodology}

2.1. Sampling and Data Collection. An initial survey which enabled rapid familiarity of the areas and communities involved in kola nut production, processing, and marketing in Ghana was conducted. Based on the survey, it was 
projected that kola nut farmers could be identified in about 129 communities across the agroecological zones in Ghana. The conjectured total number of kola nut farmers and pickers from some chief farmers and key informants such as extension agents suggested that there could be about 800 kola farmers and 1,100 pickers with about $80 \%$ of farmers from the Eastern Region of Ghana.

Following the survey, a structured questionnaire was developed and pretested with kola nut farmers, processors, and traders at Oyoko in the Eastern Region of Ghana. The questionnaire was reviewed and modified based on feedback obtained from the pretesting. During the formal survey, the snowballing technique was used, since there was no list of the farmers, processors, and traders, to enhance a simple random sampling. Four hundred and six (406) smallholders, which included farmers, pickers, processors, brokers, and traders/marketers in eighty-four (84) communities within twenty-two (22) districts in the southern regions of Ghana, were interviewed (Table 1) from May to November 2018.

2.2. Data Analysis. Data was entered into Statistical Package for Social Science (SPSS, Version 22), cleaned, and analysed. Descriptive analyses, involving the use of frequencies, percentages, and plotting of geographical coordinates were employed to assess the distribution of kola nut farmers and pickers across the country. In addition, the production practices, constraints to production, production trends, and marketing structures and constraints were assessed descriptively.

\section{Results and Discussion}

3.1. Characteristics of Respondents. The majority of the respondents across the various categories of actors were married (Table 2). Contrary to the findings of Asamoah et al. [20], females were predominantly involved in picking, processing of the nuts, and trading, while production was majorly undertaken by males. With the exception of three farmers who had a tertiary level of education, none of the other actors had a tertiary level of education. Though these actors had a low level of education, they may possess very valuable knowledge in all aspects of kola nut production, processing, and marketing which could be beneficial in the development of scientific technologies acceptable to the farmers [8]. There was no kola nut farmer association for farmers to affiliate with (Table 2). While farmers were mostly natives of the communities, the traders/marketers were mostly settlers.

3.2. Farmer Practices and Production. Some farmers (43\%) (Table 3) inherited their land for kola nut cultivation and a very few $(0.5 \%)$ had their land for kola nut cultivation on lease arrangements. Other farmers (40\%) inherited already established kola nut farms from their relatives. This is a very common practice in many kola nut growing areas in West Africa $[8,22]$. Most of those who established kola nut trees by themselves $(82 \%)$ obtained planting materials from neighbouring farms (Table 3 ). The gestation period of most (54\%) kola farms was 4-6 years and the dominant colour
TABLE 1: Status of respondents in the survey.

\begin{tabular}{lcc}
\hline Respondent's status & Frequency & Percentage \\
\hline Farmer only & 125 & 30.8 \\
Picker only & 77 & 19 \\
Broker only & 9 & 2.2 \\
Processor only & 2 & 0.5 \\
Marketer only & 23 & 5.7 \\
Broker + marketer & 3 & 0.7 \\
Farmer + broker & 1 & 0.2 \\
Farmer + marketer & 4 & 1 \\
Farmer + picker & 17 & 4.2 \\
Farmer + picker + processor & 1 & 0.2 \\
Farmer + picker + processor + broker & 10 & 2.5 \\
Farmer + picker + processor + marketer & 2 & 0.5 \\
Farmer + processor & 12 & 3 \\
Farmer + processor + broker & 7 & 1.7 \\
Farmer + processor + marketer & 9 & 2.2 \\
Picker + broker & 6 & 1.5 \\
Picker + broker + marketer & 2 & 0.5 \\
Picker + processor & 10 & 2.5 \\
Picker + processor + broker & 12 & 3 \\
Picker + processor + broker + marketer & 3 & 0.7 \\
Picker + processor + marketer & 7 & 1.7 \\
Processor + broker & 23 & 5.7 \\
Processor + broker + marketer & 12 & 3 \\
Processor + marketer & 29 & 7.1 \\
Total & 406 & 100 \\
\hline
\end{tabular}

type harvested by farmers was white (Table 3). The white nuts were dominant in the Eastern region while the red nuts were dominant in the Western region (Figure 3). The white kola nut had gained much popularity for commerce in the Eastern Region due to its preference by customers or traders in mostly Nigeria. Thirty-eight (38) percent of the farmers had sole kola nut farms while $62 \%$ had kola trees as an intercrop in their cocoa farms (Table 3). This is consistent with findings of studies in the Ivory Coast on cocoa-kola intercrop by Sanial and Ruf [23]. The area planted to sole kola nut was about $50 \%$ of the area planted to cocoa-kola intercropped farms (Figure 4).

The cocoa-kola intercrop was a very common practice by many kola farmers in the Eastern and Volta Regions of Ghana. This was because most of these farmers found the kola nut as an alternative source of livelihood. During the survey, some farmers noted that the kola nut trees were very resilient to harsh weather conditions, such that during, seasons of extended drought, many cocoa trees died, but the kola nut trees continued to produce nuts. In Nigeria, studies by Ekanade [24] and Oladokun and Egbe [25] noted that though yields of respective crops in a cocoa-kola association decrease, the area equivalency ratio is better than for monocultures. Nonetheless, farmers in Ghana and Cote d'Ivoire have been discouraged from intercropping cocoa farms with kola trees with the notion that kola trees encourage the growth and spread of mistletoes on cocoa farms [23]. This advice has, however, been disregarded by many cocoa farmers. The general disregard of this advice by the farmers reflects researchers and extension workers' lack of understanding of farmer practices and the kola tree's economic, social, and cultural role [23]. More recently, Osei and 
TABLE 2: Characteristics of respondents.

\begin{tabular}{|c|c|c|c|c|c|c|}
\hline \multirow{2}{*}{ Variable } & \multirow{2}{*}{ Level } & \multicolumn{5}{|c|}{ Category of respondents (frequencies) } \\
\hline & & Farmers & Pickers & Processors & Brokers & Marketers/traders \\
\hline \multirow{2}{*}{ Gender } & Male & 120 & 15 & 38 & 3 & 38 \\
\hline & Female & 67 & 132 & 101 & 84 & 56 \\
\hline \multirow{5}{*}{ Marital status } & Married & 142 & 101 & 110 & 65 & 76 \\
\hline & Single & 4 & 9 & 2 & 2 & 1 \\
\hline & Widowed & 24 & 15 & 15 & 12 & 10 \\
\hline & Divorced & 16 & 18 & 12 & 8 & 7 \\
\hline & Cohabitation & 1 & 4 & 0 & 0 & 0 \\
\hline \multirow{6}{*}{ Level of education } & None & 34 & 29 & 31 & 22 & 23 \\
\hline & Up to primary school & 26 & 39 & 33 & 25 & 20 \\
\hline & JHS/middle school & 111 & 77 & 63 & 37 & 31 \\
\hline & Secondary/vocational/technical & 12 & 1 & 3 & 2 & 5 \\
\hline & Tertiary & 3 & 0 & 0 & 0 & 0 \\
\hline & Nonformal education & 1 & 1 & 9 & 1 & 15 \\
\hline \multirow{2}{*}{ Member of association } & Yes & 0 & 1 & 2 & 1 & 3 \\
\hline & No & 187 & 146 & 137 & 86 & 91 \\
\hline \multirow{2}{*}{ Migration status } & Native & 106 & 73 & 50 & 41 & 14 \\
\hline & Settler & 81 & 74 & 89 & 46 & 80 \\
\hline Total & & 187 & 147 & 139 & 87 & 94 \\
\hline
\end{tabular}

JHS: junior high school.

TABLe 3: Characteristics of kola farms.

\begin{tabular}{|c|c|c|}
\hline Variable & Level & Percentage \\
\hline \multirow{8}{*}{ Source of land for kola cultivation $(N=187)$} & Purchased & 4.3 \\
\hline & Rented/leased & 0.5 \\
\hline & Gift & 20.2 \\
\hline & Sharecropped & 18.6 \\
\hline & Inherited & 42.6 \\
\hline & Allocated free & 1.6 \\
\hline & Caretaking & 2.7 \\
\hline & Family land & 9.6 \\
\hline \multirow{3}{*}{ Established kola trees by self $(N=187)$} & Yes all trees & 39.9 \\
\hline & No & 39.9 \\
\hline & Yes some trees & 20.2 \\
\hline \multirow{3}{*}{ Source of planting material $(N=113)$} & Other farmers' farms & 82.3 \\
\hline & CRIG & 4.4 \\
\hline & Bush & 13.3 \\
\hline \multirow{2}{*}{ Status of farm $(N=187)$} & Sole kola & 37.8 \\
\hline & Intercrop & 62.2 \\
\hline \multirow{3}{*}{ Dominant colour $(N=187)$} & Red & 10.6 \\
\hline & White & 88.5 \\
\hline & Pink & 1 \\
\hline \multirow{4}{*}{ Gestation period of kola planted by respondents (104) } & $1-3$ years & 4.8 \\
\hline & 4-6 years & 53.8 \\
\hline & 7-9 years & 37.5 \\
\hline & $10+$ years & 3.8 \\
\hline
\end{tabular}

Ansong [26] have indicated that mistletoe density on cocoa farms was mainly influenced by spatial arrangement of cocoa trees, while shade tree diversity and density, respectively, had a significantly negative and no relationship with mistletoe density. This confirms that kola nut trees may not be the main source of mistletoes on cocoa farms and may support why some cocoa farmers have disregarded the advice to remove intercropped kola nut tree.
Nearly all the farmers (99.5\%) had not received any training on agronomic practices. Kola was mostly planted in random spacing and farmers weeded averagely twice per year. A few farmers (4.3\%) planted in regular spacing at between $10 \mathrm{ft} \times 10 \mathrm{ft}$ and $30 \mathrm{ft} \times 30 \mathrm{ft}$. About $25 \%$ of the farmers applied fertilizer to their kola farms at least once a year and about 78\% had never pruned their farms (Table 4). Forty-four (44) percent of them had cut their kola farms. Of 


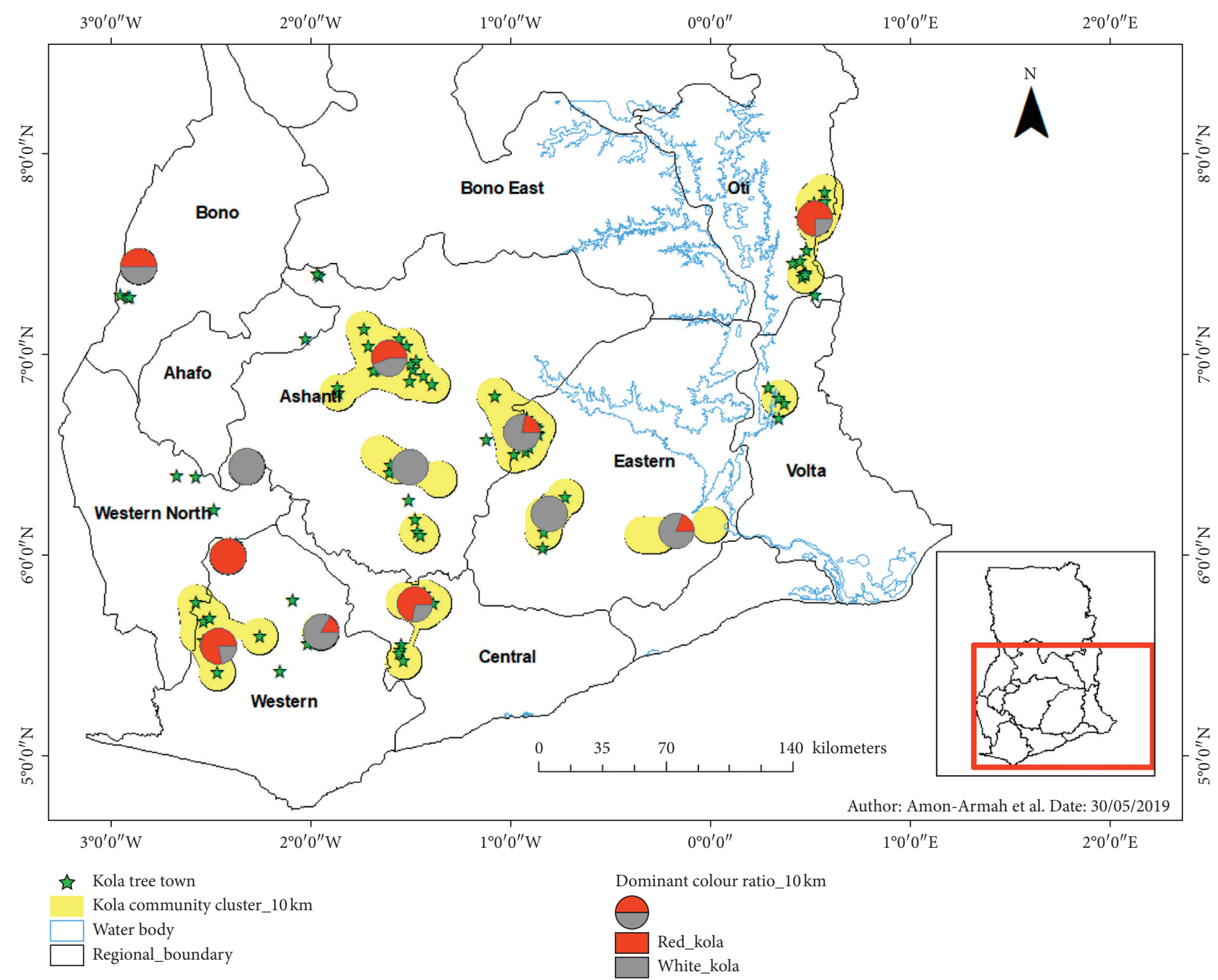

FIgURE 3: Map showing proportions of kola nut colour in clusters of $10 \mathrm{~km}$ radius in the surveyed areas.

these, 98.8\% did not cut all the farm but cut-out an average of $80 \%$ and replaced mostly with cocoa trees (42\%) (Table 4 ). While the average age of the kola farms was 24 years, the farmers managed an average acreage of 3.4 acres. Most of the farms were planted between the 1980s and the 2000s (Figure 5).

Generally, between 2015 and 2017, a slight increase was observed for the total area under kola production for the respondents (Table 5). A similar trend was observed within every cluster of $10 \mathrm{~km}$ radius, except for clusters in Bono and Western South Regions (Figure 6).

3.3. Pest and Disease Management. Most farmers (53\%) could not mention any disease of kola that affected kola trees; however, some farmers mentioned certain pests and diseases as constraining kola nut cultivation. Mistletoes $(70.6 \%)$ and ants (both red and black (51.9\%)) were the most stated pests (Table 6). Similarly, farmers mentioned a disease they described as "jerry" (11.7\%) that affected the kola nut trees (Figure 7). Others mentioned another disease they call "turu" (4.3\%) which affected the nuts harvested from the field (Figure 7). Farmers managed the diseases that affected the trees by cutting off the affected part of the kola tree and also managed the ants using insecticides meant for their cocoa (Table 6).

3.4. Constraints and Motivations to Production. Several constraints militating against kola nut cultivation were reported by farmers. The low market price of nuts $(61.5 \%)$, pests and diseases (60.4\%), and lack of inputs (45.5\%) were the most reported (Table 7). In spite of the constraints, farmers were motivated by several factors to continue cultivating kola nuts. Chiefs among these motivating factors were alternative livelihood support (58\%), followed by the source of income (34.3\%) (Figure 8). The findings are consistent with [23].

Farmers suggested several solutions which they perceived could mitigate their constraints and enhance kola nut cultivation in Ghana (Table 8). Majorly mentioned were the provision of farm input provision (57.7\%), followed by the regulating of the marketing system for price stability, and ready market as it has been for cocoa in Ghana $(54.2 \%)$ and extension service support (training and sensitization) for kola farmers $(24.8 \%)$. 


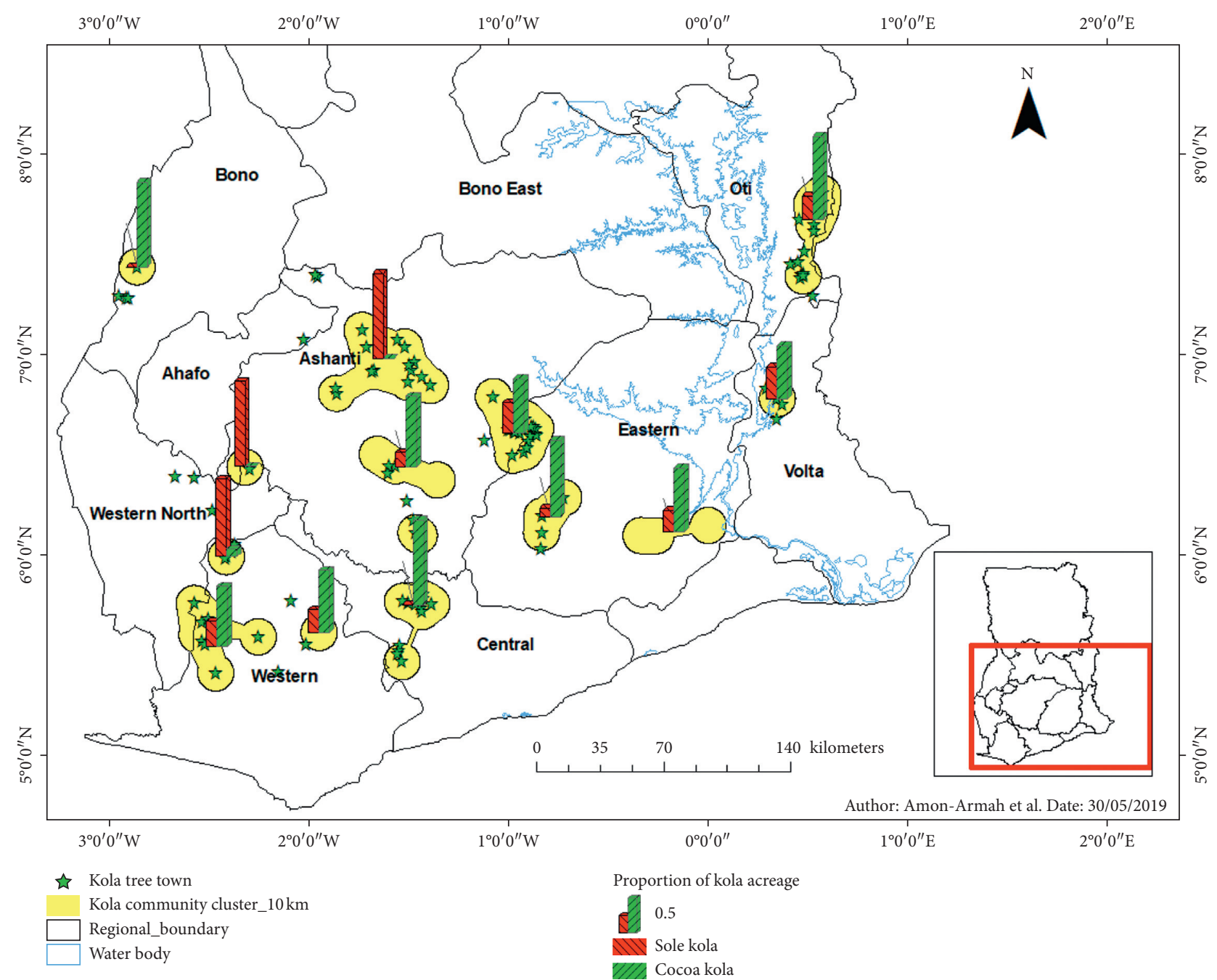

Figure 4: Map showing proportions of sole kola nut farms to cocoa-kola farms in clusters of $10 \mathrm{~km}$ radius in the surveyed areas.

3.5. Processing of Kola Nuts in Ghana. Sorting of kola nuts before selling to marketers was done by most of the processors $(60.8 \%)$ mainly to eliminate mouldy nuts $(85.2 \%)$ and insectdamaged nuts (71.7\%) (Table 9). Most processors $(83.7 \%$ ) found at most $10 \%$ of nuts are mouldy (Figure 9) during sorting and discarded these mouldy nuts posing an economic loss (Table 9). Depulping of nuts was done by $48.0 \%$ of the processors. Most of these processors depulped the nuts by soaking in water $(82.7 \%)$ followed by heaping on the floor and trampling with feet $(49.0 \%)$. About twenty-nine percent $(28.6 \%)$ out of the majority $(89.8 \%)$ of the processors who rinsed their kola nuts with water after depulping added some chemicals to the water (Table 9). Consistent with Asamoah et al. [20], these chemicals include Gastoxin (aluminium phosphide) and other fumigation tablets which are locally called "bomb," and Gammalin 20 (Lindane). The most used chemical for rinsing the nuts was Akate Master (bifenthrin) (54.2\%) (Figure 10). These chemicals, however, may have attendant health hazards for both users and consumers. There is a need for research to aid these processors on the use of appropriate hazard-free treatment methods and the correct dosage and application procedures for treating the nuts.
Kola nuts are usually bagged and preserved for storage while waiting for enough quantity to sell to traders or marketing agents within the country or across the borders. In the past, several kola nut storage experiments have reported successful storage methods $[10,11]$. A serious setback noticed from these experiments has been the tainting recorded with the use of the chemicals for storage. Nonetheless, processors continue to use their indigenous ways to preserve the nuts to prevent losses to kola weevils and fungi. Processors usually store by bagging nuts in sacks lined with leaves (81.9\%) (Figure 11). The majority (51.0\%) of the processors who cured nuts during storage mostly used fumigation tablets (91.0\%) (Table 10), which may be dangerous to their health and that of consumers in the long run. Most processors doubled as marketers, while a few only processed and sold nuts to marketers for further curing before final sales to consumers or exporters. Eighty-three percent $(83.4 \%)$ of the processors who cured their nuts intermittently sorted out bad nuts, looking out mostly for mouldy (83.7\%) and germinated or sprouted nuts (65.7\%) (Table 10).

Several studies (e.g., $[13,27,28])$ noted that the traditional way of preserving kola nuts led to significant losses by 
TABLE 4: Kola nut farmers' cultural practices and extension.

\begin{tabular}{|c|c|c|}
\hline Variable & Level & Percentage \\
\hline \multirow{2}{*}{ Agronomic practices $(N=187)$} & Yes & 0.5 \\
\hline & No & 99.5 \\
\hline \multirow{2}{*}{ Ever applied fertilizer $(N=187)$} & Yes & 24.5 \\
\hline & Never & 75.5 \\
\hline \multirow{2}{*}{ Planting method used $(N=187)$} & Random & 95.7 \\
\hline & Regular spacing & 4.3 \\
\hline \multirow{5}{*}{ Spacing $(N=8)$} & $10 \mathrm{ft} \times 10 \mathrm{ft}$ & 12.5 \\
\hline & $20 \mathrm{ft} \times 20 \mathrm{ft}$ & 25 \\
\hline & $25 \mathrm{ft} \times 25 \mathrm{ft}$ & 25 \\
\hline & $28 \mathrm{ft} \times 28 \mathrm{ft}$ & 25 \\
\hline & $30 \mathrm{ft} \times 30 \mathrm{ft}$ & 12.5 \\
\hline \multirow{2}{*}{ Ever pruned $(N=187)$} & Yes & 22.3 \\
\hline & No & 77.7 \\
\hline \multirow{2}{*}{ Ever cut part or all of your kola farm $(N=187)$} & Yes & 44.1 \\
\hline & No & 55.9 \\
\hline \multirow{2}{*}{ Specify the cutting done $(N=83)$} & Part of the kola farm/trees & 98.8 \\
\hline & Entire kola farm/trees & 1.2 \\
\hline \multirow{6}{*}{ Crops planted after cutting was done $(N=83)$} & None & 41 \\
\hline & Cocoa & 42.2 \\
\hline & Kola & 1.2 \\
\hline & Citrus & 1.2 \\
\hline & Food crops & 10.8 \\
\hline & Oil palm & 3.6 \\
\hline Variable & Mean & Standard error \\
\hline Average proportion of kola farm cutout of 10 & 8.0 & 0.19 \\
\hline Average frequency of fertilizer application in a year & 1.0 & 0.12 \\
\hline Average frequency of weeding & 2.0 & 0.05 \\
\hline
\end{tabular}

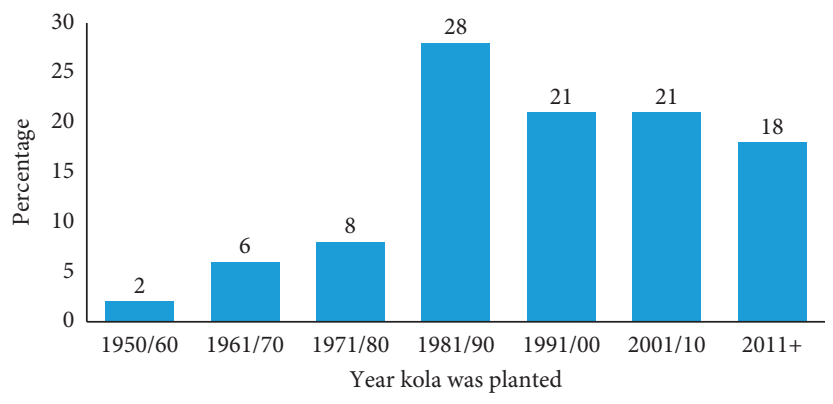

Figure 5: Year in which respondents planted kola trees.

TABLE 5: Area under cultivation and production of kola nuts.

\begin{tabular}{lccc}
\hline Year & 2015 & 2016 & 2017 \\
\hline Total acreage managed by respondents & 519.50 & 532.00 & 553.50 \\
Average acreage cultivated by respondents* & $3.37(0.21)$ & $3.39(0.21)$ & $3.38(0.20)$ \\
Total number of bags harvested by respondents & 725.2 & 716.2 & 792.8 \\
\hline
\end{tabular}

${ }^{*}$ Figures in parenthesis are standard errors. 1 bag of raw nuts (with its skin) is equivalent to $160 \mathrm{~kg}$ of depulped nuts.

way of insect infestation, in situ germination, shrinkage, bolting, and mouldiness. Preserving the kola nuts as indicated by the majority (94.5\%) of the processors was done by the following: (i) Putting nuts in sacks or baskets lined with either leaves of the Marantaceae family including "Anwonomo/Aworomo" (Thaumatococcus daniefii) and "Subaha" (Marantochloa spp.) or polythene 


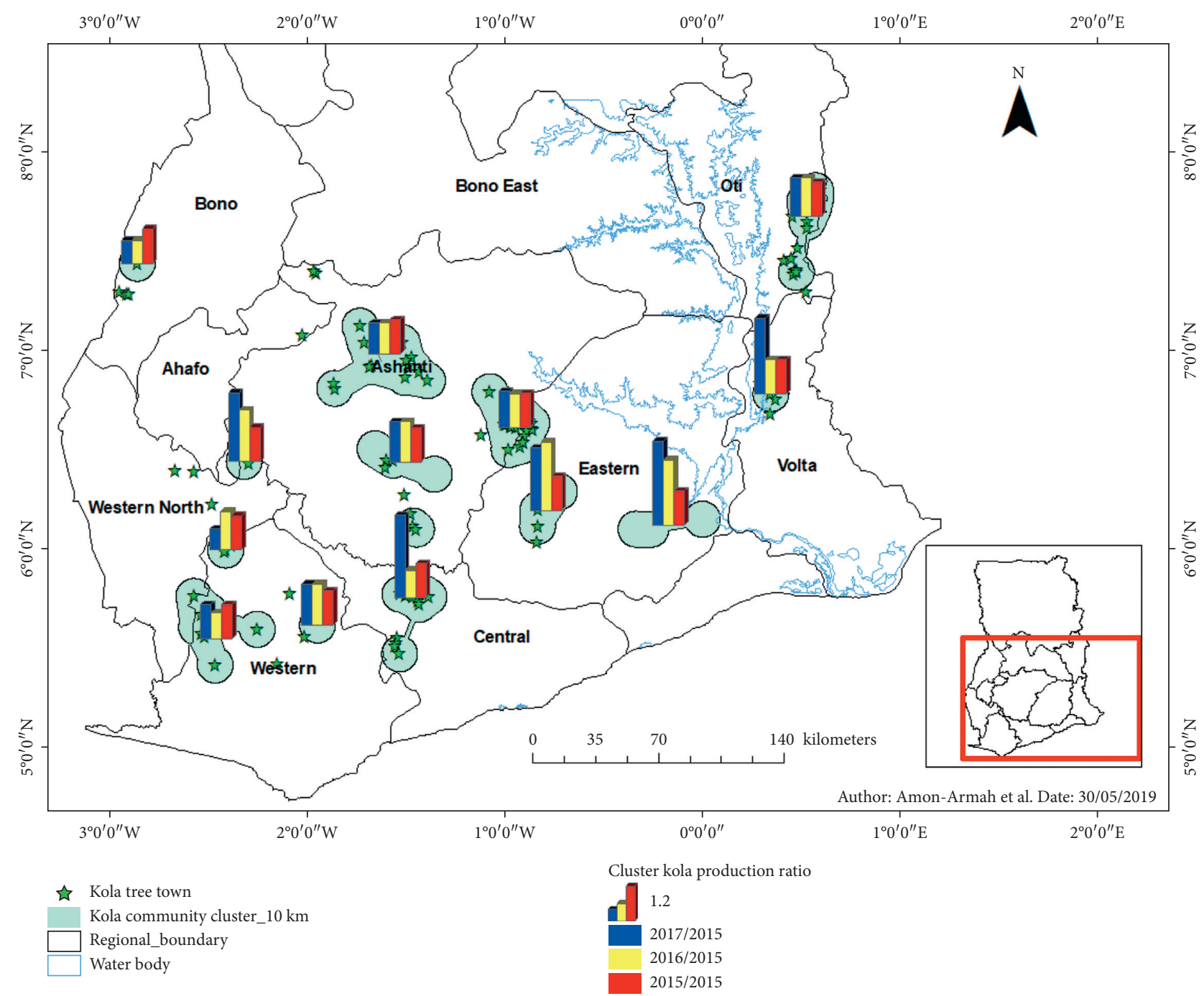

FIGURE 6: Map showing kola production trend in clusters of $10 \mathrm{~km}$ radius in the surveyed areas.

TABle 6: Pests/insects and diseases of kola cultivation.

\begin{tabular}{|c|c|c|c|}
\hline Variable & Level & Frequency & Percentage \\
\hline \multirow{7}{*}{$\begin{array}{l}\text { Major pests/insects affecting kola } \\
\text { cultivation (multiple responses, } N=290 \text { ) }\end{array}$} & Ants (red and black) & 83 & 51.9 \\
\hline & Worms (“Nkontia") & 44 & 27.5 \\
\hline & Mistletoes & 113 & 70.6 \\
\hline & Stem borers & 17 & 10.6 \\
\hline & Grasshoppers & 1 & 0.6 \\
\hline & Other epiphytes & 31 & 19.4 \\
\hline & Termites & 1 & 0.6 \\
\hline \multirow{4}{*}{ How pests/insects are managed $(N=171)$} & Cutting off affected part or tree & 80 & 46.8 \\
\hline & Applying chemicals (e.g., use of confidor, Akate Master, and ashes) & 18 & 10.5 \\
\hline & Both (cultural and chemical means) & 18 & 10.5 \\
\hline & None (not managed) & 55 & 32.2 \\
\hline \multirow{5}{*}{$\begin{array}{l}\text { Major diseases affecting kola cultivation } \\
(N=188)\end{array}$} & "Jerry" (curled leaves) & 22 & 11.7 \\
\hline & "Turu" (black spots on nuts and rot inside the nuts) & 8 & 4.3 \\
\hline & $\begin{array}{l}\text { Cannot tell disease name but symptoms (abnormal reddening of } \\
\text { leaves, die-back, empty and prematured falling of pods, etc.) }\end{array}$ & 17 & 9.0 \\
\hline & None (no disease affects kola) & 42 & 22.3 \\
\hline & Do not know (whether or not there is any disease) & 99 & 52.7 \\
\hline \multirow{3}{*}{ How diseases are managed $(N=47)$} & Cutting off affected part or tree or discarding affected nuts & 16 & 34.0 \\
\hline & Spraying of chemical (insecticides-confidor, Akate Master) & 2 & 4.3 \\
\hline & None (not managed) & 29 & 61.7 \\
\hline
\end{tabular}




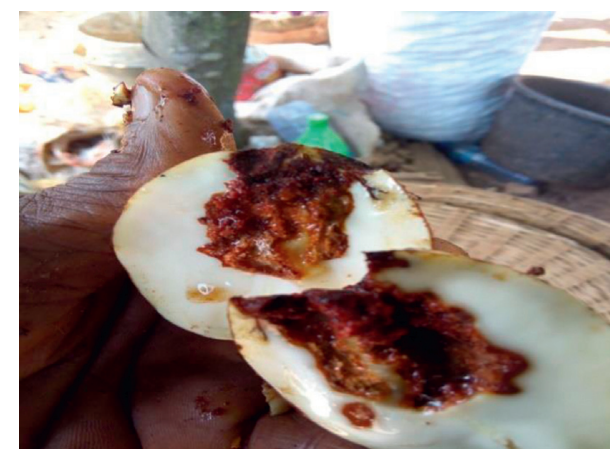

(a)

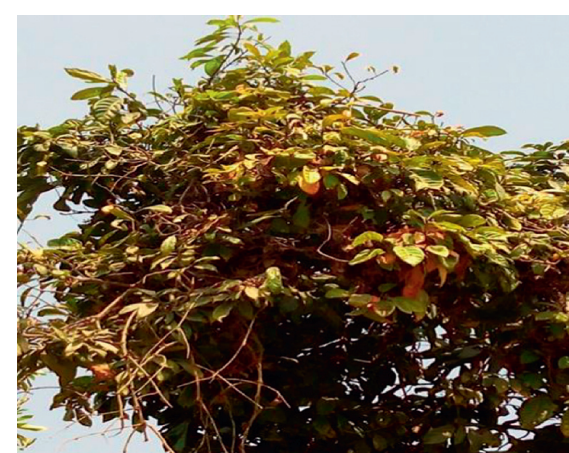

(b)

Figure 7: (a) A disease referred to as "Turu" by kola farmers caused by kola nut weevil. (b) A disease referred to as "Jerry" by kola farmers in Nkawkaw.

TABLE 7: Major constraints to kola production.

\begin{tabular}{lcc}
\hline Constraints & $N^{*}$ & Percent $^{*}$ responses \\
\hline Lack of planting materials & 21 & 7.3 \\
Lack of market & 79 & 27.4 \\
Low/poor market price of nuts (price fluctuation) & 177 & 61.5 \\
Lack of information on grower recommendation & 82 & 28.5 \\
Lack of credit facilities (financial challenge) & 32 & 11.1 \\
Problems of bush fires & 1 & 0.3 \\
Poor weather conditions & 14 & 4.9 \\
Lack of inputs (including protective clothing) & 131 & 45.5 \\
Pests and diseases & 174 & 60.4 \\
Labour challenge & 11 & 3.8 \\
Harvesting challenge (due to tree's height and size) & 5 & 1.7 \\
Theft issues & 9 & 3.1 \\
Poor bearing of kola trees & 10 & 3.5 \\
\hline
\end{tabular}

* Multiple responses.

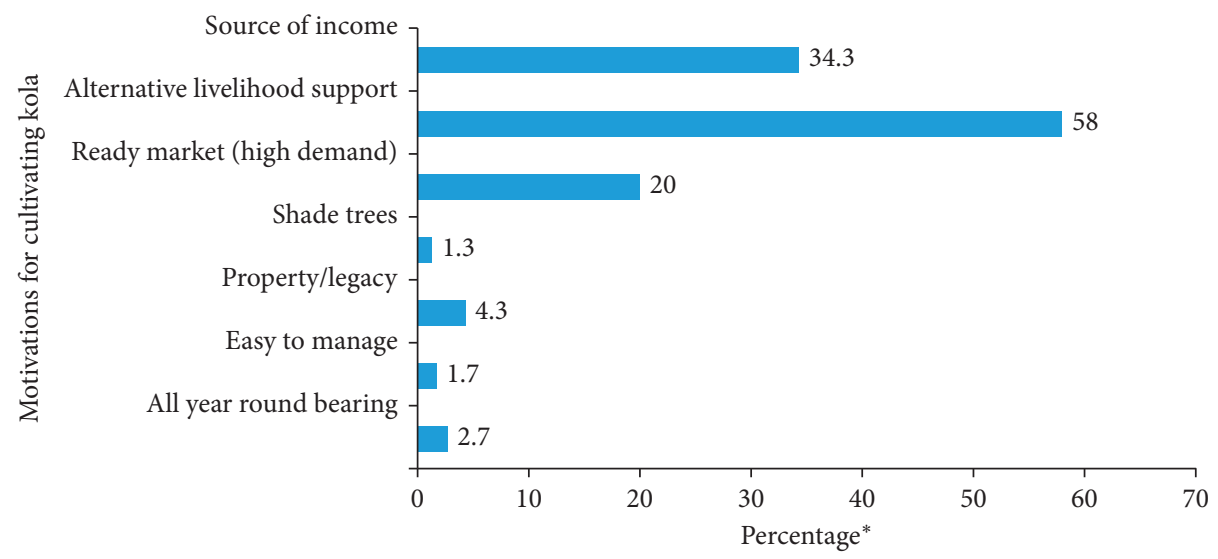

Figure 8: Motivation factors for the cultivation of kola ( ${ }^{*}$ multiple responses).

(ii) Adding of fumigation tablet (sometimes wrapped in a cotton or piece of perforated cloth/leaf)

(iii) Sorting out the nuts intermittently (Table 11)

The nuts are usually stored for a period of 1-3 months $(81.3 \%)$ before either selling or further preservation or sorting (Figure 12). However, it has been noted by Asamoah et al. [20] that most of the chemicals used by the processors could be very toxic to human health. These chemicals have not been approved by the Environmental Protection Agency (EPA) and the Food and Drug Authority (FDA) of Ghana for safety in preserving the nuts which are mostly chewed by consumers. In addition, the right dosage is not known. While the kola nut industry exits and the practices of 
TABLE 8: Suggested solutions to constraints faced in kola cultivation.

\begin{tabular}{lcc}
\hline Solution & $N^{*}$ & Percentage* $^{*}$ \\
\hline Extension service support (for training and sensitization) & 71 & 24.8 \\
Credit facility (financial) support & 18 & 155 \\
Regulated marketing system (for price stability and ready market as in cocoa) & 165 & 5.3 \\
Input support (e.g., chemicals, improved variety, and protective clothing) for management & 25 & 57.2 \\
Availability of grower (both preharvest and postharvest) recommendation & 3 & 8.7 \\
Availability and accessibility of land for cultivation & 437 & 1.0 \\
Total & & 152.8 \\
\hline
\end{tabular}

${ }^{*}$ Multiple responses.

TABLE 9: Kola nut processing practices in Ghana.

\begin{tabular}{|c|c|c|}
\hline Variable & Level & Percentage \\
\hline \multirow{2}{*}{ Are kola nuts sorted before processing/selling? $(N=401)$} & Yes & 60.8 \\
\hline & No & 39.2 \\
\hline \multirow{4}{*}{$\begin{array}{l}\text { Things looked out for during sorting (multiple responses, } \\
N=452 \text { ) }\end{array}$} & Mouldiness & 85.2 \\
\hline & Insects damaged & 71.7 \\
\hline & Sizes (big/small) & 14.8 \\
\hline & Colour (red/white/pink) & 13.5 \\
\hline \multirow{4}{*}{ How are mouldy nuts treated? $(N=208)$} & $\begin{array}{c}\text { Less mouldy nuts are sold locally for local consumption at a low } \\
\text { price }\end{array}$ & 14.9 \\
\hline & Kept for personal use (chewing) & 0.5 \\
\hline & Buyers take it free & 1.0 \\
\hline & Thrown away (discarded) & 83.7 \\
\hline \multirow{4}{*}{ Are nuts depulped by you? $(N=402)$} & Yes & 48.0 \\
\hline & No, I buy already depulped nuts & 2.7 \\
\hline & No, I sell/give them out with the pulp & 44.5 \\
\hline & Both (I depulp some and I buy some already depulped) & 4.7 \\
\hline \multirow{4}{*}{ How kola nuts are depulped (multiple responses, $N=311$ ) } & Soaking in water & 82.7 \\
\hline & Heaping on the floor and trampling with feet & 49.0 \\
\hline & Put in moistened jute sacks & 6.3 \\
\hline & Use of a knife/a piece of stick & 11.5 \\
\hline \multirow{2}{*}{ Are kola nuts rinsed with water after depulping? $(N=226)$} & Yes & 89.8 \\
\hline & No & 10.2 \\
\hline \multirow{2}{*}{ Any chemical added to the water for rinsing? $(N=203)$} & Yes & 28.6 \\
\hline & No & 71.4 \\
\hline
\end{tabular}

preserving and storing nuts continues, we suggest the urgent need for research to identify the types of chemicals that could be less harmful but very efficient in safely preserve the nuts and in addition standardize the application levels (e.g., dosage) for the preservation processes.

3.6. Marketing of Kola Nuts in Ghana. About $42 \%$ of the respondents noted that traders preferred white kola nuts to red nuts (Table 12). Meanwhile, about $40 \%$ indicated the preference by traders for red kola nuts. Respondents who indicated the preference of the white nuts to the red nuts mostly opined that (i) the white nuts were largely patronized by foreign customers and consumers (Table 12), hence high demand, and (ii) it was always readily available since plantation handed over to them were mostly of the white kola nut. This is consistent with the findings of Ndagi et al. [8] in Nigeria. Other reasons were that the white kola tasted better and nut sizes were larger (Table 12). The white kola nut has gained popularity and preference in interregional and international trade and hence of major economic importance $[8,29,30]$. On one hand, respondents who gave reasons for the preference of the red nuts mostly noted that the red nuts were able to withstand diverse conditions during transportation and had longer shelf life compared with the white nuts (Table 12). This comparative assessment of the white and red kola nuts provides useful information to demand-driven breeding research for desired characteristics for both consumers and traders.

Kola nuts were mostly sold to buyers/agents within the villages/communities (43.3\%) and those from district capital (31.4\%) in smaller units of measurement such as the use of “34 bucket" (18 L containers) (76.3\%) and basin/rubber bowl (4 L containers) (10.3\%) (Table 13).

Information flow on the market transaction such as price determination and standard measurements was limited. There was no standard pricing or grading for kola nut in Ghana similar to Nigeria and other African countries [31]. Market transaction information on price determination, measurements, sizes of nuts, and the quality of nuts/grading 


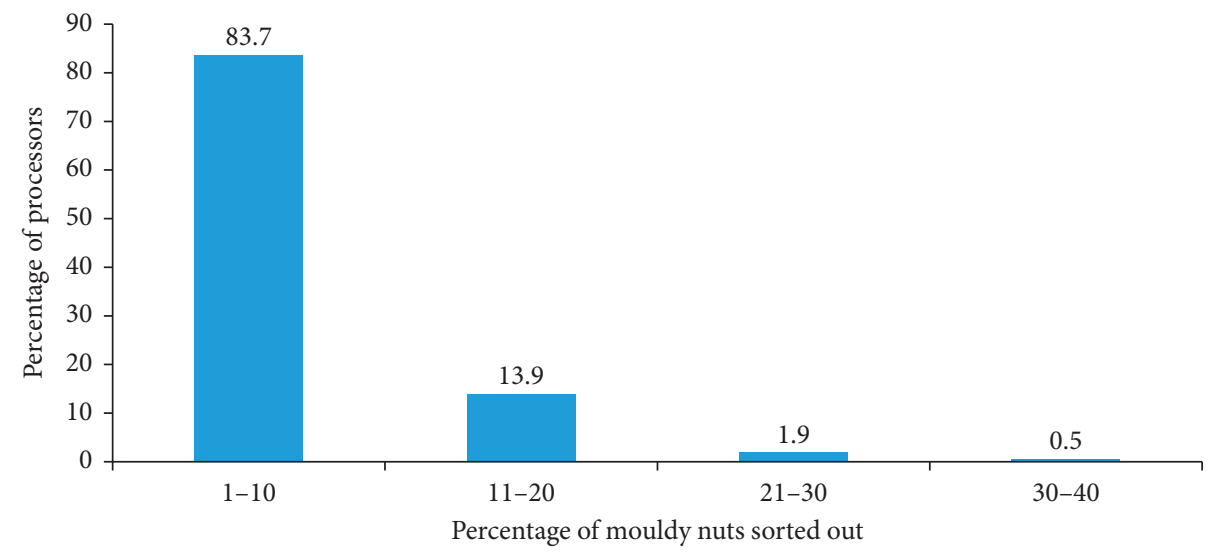

FIGURE 9: Percentage of mouldy nuts identified during sorting by processors.

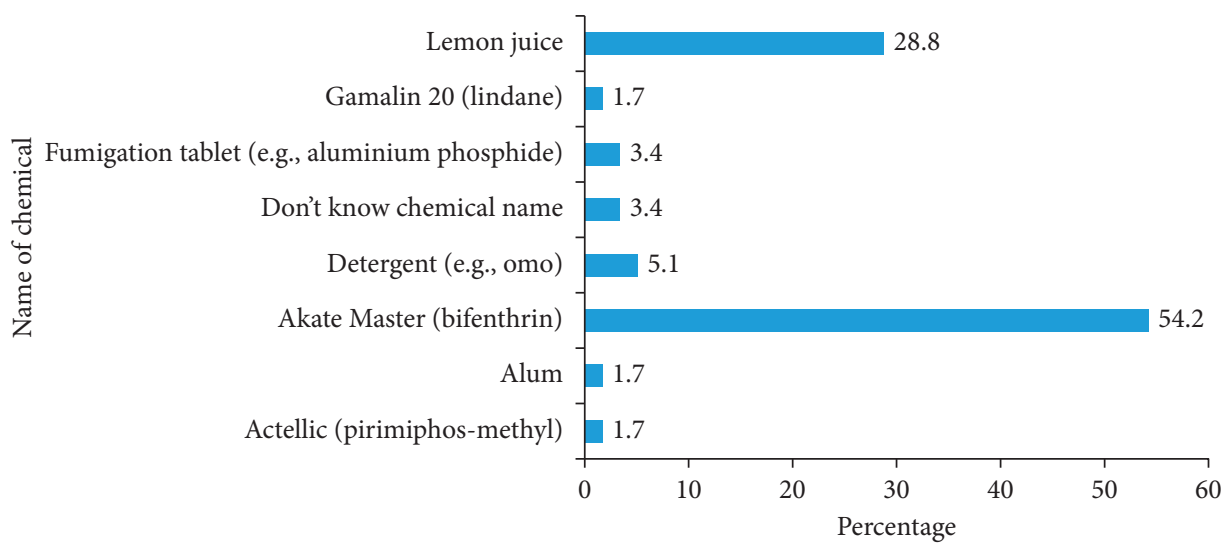

FIgURE 10: Chemicals used in solution for rinsing kola nuts.

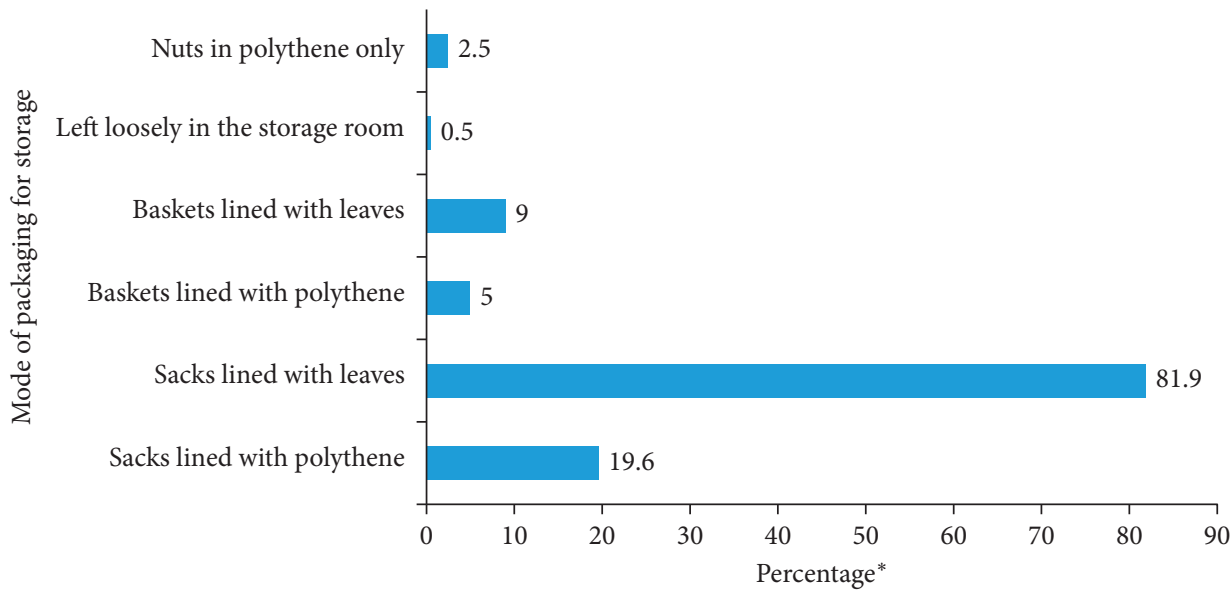

FIgURE 11: Packaging kola nuts for storage ( ${ }^{*}$ multiple responses).

was based on mutual knowledge and understanding of the parties involved (buyers and sellers). Majority (73\%) of the merchants used the "size 34 bucket" (about 18 litres) as their standard of measurement (Table 13). Buyers were mainly traders within the community (43.3\%) who stored much and exported and buyers from the capital of the district within which they operated (31.4\%). A few traders (3.4\%) came from Burkina Faso and Ivory Coast to buy kola nuts in the communities.

It was noticed that the quantity of kola nuts sold by traders and the price increased over time (Table 14). However, traders preferred an average of about $61 \%$ more for the price received in 2017 for a bag of kola nuts (Table 14). 
TABle 10: Preservation of kola nuts during storage to increase shelf life before sales.

\begin{tabular}{|c|c|c|c|}
\hline Variable & Level & Frequency & Percentage \\
\hline \multirow{2}{*}{ Are your kola nuts preserved? $(N=390)$} & Yes & 199 & 51.0 \\
\hline & No & 191 & 49.0 \\
\hline \multirow{6}{*}{ Chemical used for preserving $(N=199)$} & Actelic (pirimiphos-methyl) & 1 & 0.5 \\
\hline & Akate Master (bifenthrin) & 6 & 3.0 \\
\hline & Fumigation tablet (aluminium phosphide) (e.g., & 181 & 91.0 \\
\hline & $\begin{array}{l}\text { bextoxin, agroxin, and dastoxin) } \\
\text { Insecticide powder }\end{array}$ & 2 & 1.0 \\
\hline & Gamalin 20 (lindane) & 1 & 0.5 \\
\hline & Cannot tell chemical name & 8 & 4.0 \\
\hline \multirow{2}{*}{ Is sorting out done during curing? $(N=199)$} & Yes & 166 & 83.4 \\
\hline & No & 33 & 16.6 \\
\hline \multirow{6}{*}{$\begin{array}{l}\text { Things looked out for when sorting during curing } \\
\text { (multiple responses, } N=351 \text { ) }\end{array}$} & Mouldy (rotten) nuts & 139 & 83.7 \\
\hline & Germinated/sprouted nuts & 109 & 65.7 \\
\hline & Insect damaged nuts & 73 & 44.0 \\
\hline & Shrunk/burnt nuts & 23 & 13.9 \\
\hline & Colour (red or white) & 4 & 2.4 \\
\hline & Size (big or small) & 3 & 1.8 \\
\hline
\end{tabular}

TABLE 11: Processes of packaging and preservation of the kola nuts for storage by the respondents $(N=199)$.

Packaging and preservation process

Percentage

Put nuts in sacks/baskets lined with leaves/polythene-add fumigation tablet (in cotton/piece of perforated cloth/leaf), cover sacks/baskets with leaves, store, sort intermittently

Rinse nuts in chemical solution-dry and put in basket lined with leaves, no chemical added, cover basket with leaves, store, sort intermittently

Put nuts in black polythene bag-add fumigation tablet midway in the polythene bag, seal polythene, store, sort intermittently

Put nuts in sacks-sprinkle nuts with fumigation powder, cover sack with leaves, store, sort intermittently

Put nuts in sacks/baskets lined with leaves/polythene-sprinkle nuts with chemical solution, cover with leaves, store, sort intermittently

Total

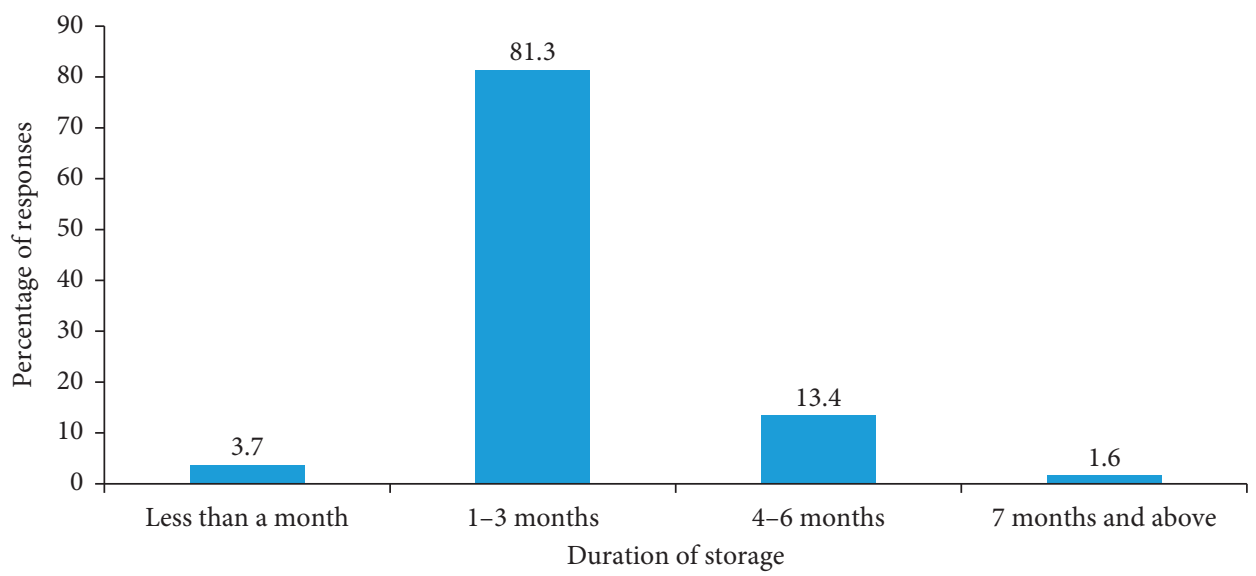

Figure 12: Duration of storage for cured nuts.

3.7. Constraints to Processing and Marketing of Kola Nuts. Several constraints militating against kola nut processing and marketing were outlined by processors and marketers during the study. The low selling price $(74.8 \%)$ of kola nuts was perceived to be the most constraint to kola nut processing and marketing followed by pests and diseases (42.9\%) with labour (1.3\%) as the least constraint to kola nut processing and marketing (Figure 13).

In respect of the constraints, the majority (95.0\%) of the respondents suggested that the marketing systems of kola 
TABLE 12: Kola nut colour preference and reasons.

\begin{tabular}{lccc}
\hline Nut colour & Red & White & Both (red and white) \\
Percentage $(N=400)$ & 40.3 & 41.5 & Total \\
100
\end{tabular}

TABLE 13: Marketing of kola nuts in Ghana.

\begin{tabular}{lc}
\hline How nuts are measured for sale & Percentage $(N=400)$ \\
\hline Use of "size 34 bucket" (18 litres) & 76.3 \\
Counting of nuts (100 pieces of nuts) & 4 \\
Use of basket & 3.3 \\
Use of sack ("bag 4") & 0.5 \\
Use of "paint rubber" & 2.5 \\
Use of basin/rubber bowl & 10.3 \\
Use of both "size 34 bucket" and counting of nuts & 1.5 \\
Use of "olonka" (4 litres) & 1.8 \\
\hline Main buyers of the nuts & Percentage (N=379) \\
\hline Trader within village/community & 43.3 \\
Trader from district capital & 31.4 \\
Trader outside district capital but in the region & 1.3 \\
Trader from another region & 6.1 \\
Trader in another country (across the border, e.g., Burkina Faso and Ivory Coast) & 3.4 \\
Other (more than one trader/agent) & 14.5 \\
\hline
\end{tabular}

TABLe 14: Price and quantity of kola nuts sold, 2015-2017.

\begin{tabular}{lccc}
\hline Variable & & Year & 2016 \\
& 2015 & $9.01(1.18)$ & 2017 \\
\hline Average quantity (bag) of nut sold per marketer* & $8.01(0.63)$ & $319.24(13.06)$ & $372.64(14.73)$ \\
Average selling price per bag (US\$) & $284.08(12.23)$ & - & $598.63(18.60)$ \\
Average selling price per bag (UD\$) by marketers* & - & -
\end{tabular}

${ }^{*}$ Figures in parenthesis are standard errors of the means. 1 bag of processed (depulped) nuts is equivalent to $248 \mathrm{~kg}$.

nuts should be taken over by the government and controlled as done for cocoa in Ghana (Figure 14). The majority of these respondents (78.8\%) said it would enhance a reliable and ready market as well as price stability in the kola industry (Table 15). Meanwhile, the few (5\%) who did not agree with the controlled marketing system like that of cocoa gave reasons such as lack of government storage facility for the nuts, fear of loss of job opportunity, and avoidance of price fixing (Table 15).

3.8. Respondents' Knowledge on the Uses of Kola Nut. Inquiring on respondents' knowledge of the uses of kola nut, most $(75.4 \%)$ responded in the affirmative and mainly indicated "chewing or consumption" (79.1\%) as the major use. Medicinal purpose (5.7\%) was the least mentioned (Table 16).

\section{Summary and Conclusion}

Kola nut farmers could be identified in about 129 communities across different agroecological zones in Ghana and were mostly natives of the communities. The majority (62\%) of the farmers had kola farms intercropped with other crops, mainly cocoa. The gestation period of most (54\%) kola farms was 4-6 years and the dominant colour type of kola nut harvested by farmers was white mostly found in the Eastern Region while 


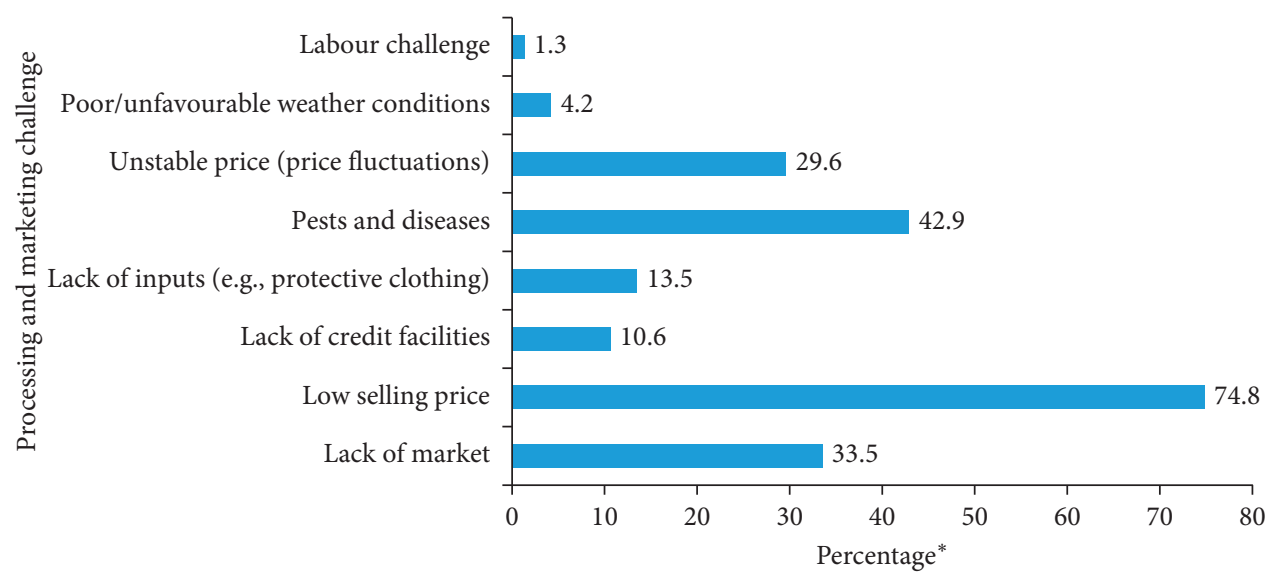

Figure 13: Constraints to kola processing and marketing in Ghana ( ${ }^{*}$ multiple responses).

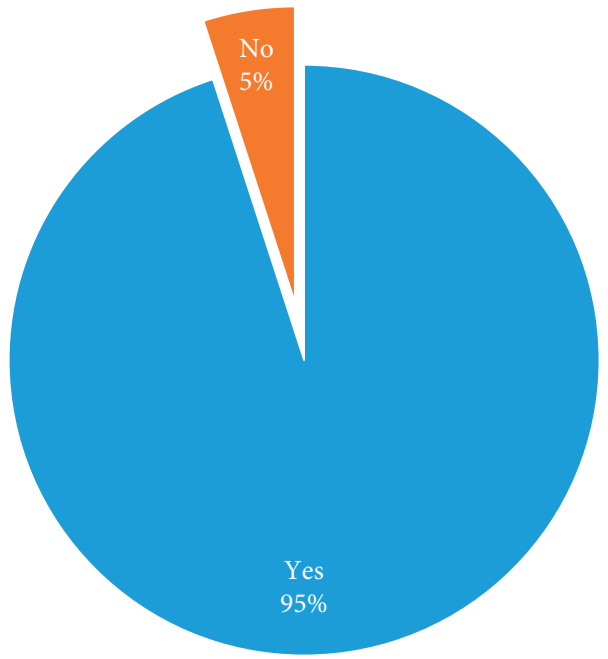

FIGURE 14: Kola nuts marketing systems should be controlled as for cocoa in Ghana $(N=403)$.

TABLE 15: Respondents' reasons for why kola nuts marketing systems should or should not be controlled as for cocoa in Ghana.

\begin{tabular}{lcc}
\hline Level of response & Reasons & Percentage \\
\hline & For standardization/accurate measurement (to prevent cheating) & 12.9 \\
& For a reliable and ready market and price stability & 78.8 \\
& To have value for the nuts as cocoa & 2.1 \\
Yes $(N=381)^{*}$ & To ensure revenue mobilization for government & 0.8 \\
& To have access to incentives and credit facilities & 2.6 \\
& For the sustainability of the kola industry & 0.8 \\
As a source of motivation and encouragement & To gain profit & 0.8 \\
No $(N=19)^{*}$ & To avoid fixed pricing (will not be profitable) & 36.3 \\
& Fear of loss of job opportunity & 36.8 \\
\hline
\end{tabular}

${ }^{*}$ Some of the respondents could not give any reason.

the red nuts were dominant in the Western Region. Nearly all the farmers (99.5\%) had not received any training on agronomic practices. Several constraints to kola cultivation were reported by farmers and these included the low market price of nuts, pests and diseases, and lack of inputs. Mistletoes and ants (both red and black) were the most mentioned pests to kola cultivation. Kola nuts are usually preserved and bagged for storage using chemicals to prevent weevil and fungi infestation to minimize storage losses. These chemicals may however be harmful to both processors and consumers. 
TABLE 16: Uses of kola.

\begin{tabular}{|c|c|c|c|}
\hline Variable & Level & Frequency & Percentage \\
\hline \multirow{2}{*}{ Knowledge of uses of kola? $(N=305)$} & Yes & 230 & 75.4 \\
\hline & No & 75 & 24.6 \\
\hline \multirow{5}{*}{ Uses of kola (multiple responses, $N=362$ ) } & Chewing & 182 & 79.1 \\
\hline & Production of drinks and beverages & 67 & 29.1 \\
\hline & Making of dye & 66 & 28.7 \\
\hline & Traditional purposes & 34 & 14.8 \\
\hline & Medicinal purposes & 13 & 5.7 \\
\hline
\end{tabular}

The respondents noted that traders preferred white kola nuts to red kola nuts due to their taste and sizes; meanwhile, about $40 \%$ indicated the preference by traders for red kola nuts since they can withstand diverse conditions and had a longer shelf life. Information on the market transaction such as price determination and measurements was based on mutual knowledge and understanding of the buyers and sellers. There were no standard prices or grading systems for kola nut in Ghana as it is for Nigeria and other African countries.

In conclusion, the study has revealed some research and policy gaps concerning the breeding and agronomy of kola nut, the post-harvest practices such as processing and storage, and marketing regulations. Building on the indigenous practices of the supply-side actors and considering their constraints, there is the need for the following:

(1) Further breeding programmes for the desired characteristics (e.g., tasty and bigger nut sizes, longer shelf life, and durability) of the kola nut for both consumers and traders.

(2) Further agronomic research to provide recommendations to farmers on best practices of farm management (including spacing or tree density, soil management, and pest and disease management) building from the indigenous practices of the farmers.

(3) Provision and intensification of extension services to disseminate recommendations on best management practices based on research findings.

(4) Research into safe integrated curing and storage methods including the provision of less harmful chemicals and their right dosages for use.

(5) Government to enable stakeholders to standardize pricing methods and grading systems for the mutual benefit of all the stakeholders.

\section{Data Availability}

The data that support the findings of this study are available on request. The data are not publicly available due to privacy restrictions of research participants.

\section{Conflicts of Interest}

The authors declare that they have no conflicts of interest regarding the publication of this study.

\section{Acknowledgments}

This research paper (CRIG/06/2021/052/005) is published with the kind permission of the Executive Director of CRIG. This research was funded by the authors' institution.

\section{References}

[1] P. E. Onomo, N. Niemenak, and D. O. Ndoumou, "Isoenzyme variability of three cola (Cola acuminata (Pal. de Beauv, Schott and Endlicher), Cola nitida ((Vent) Schott and Endlicher) and Cola anomala (Schott and Endlicher)) germplasm in Cameroon," Pakistan Journal of Biological Sciences, vol. 9, no. 3, pp. 391-397, 2006.

[2] P. O. Adebola, Genetic characterization and biosystematic studies in the genus Cola Schott and Endlicher, Ph.D. Thesis, p. 203, University of Ibadan, Ibadan, Nigeria, 2003.

[3] M. A. Dadzie, S. Y. Opoku, A. Akpertey et al., Kola Cultivation in Ghana, Cocoa Research Institute of Ghana, Eastern Region, Ghana, 2013.

[4] F. A. Squire and F. O. Iwenjora, On the Kola Tree Borer in Nigeria, Phosphorus virescens (Oliver), Federal Department of Agricultural, Research, Moor Plantation, Ibadan, Nigeria, 1963.

[5] E. U. Asogwa, A. E. Agbongiarhuoyi, F. C. Mokwunye, I. Ndagi, S. Adebiyi, and T. C. N. Ndubuaku, "The challenges of kola nuts processing, trade and export from Nigeria and other Sub-Saharan African countries," International Journal of Science and Nature, vol. 3, no. 1, pp. 6-11, 2012.

[6] FAO, "Food and agricultural organisation, country and territory data," 2013, http://faostat.fao.org/.

[7] O. Ampadu-Agyei, Non-Traditional Agricultural Exports and Natural Resource Management in Ghana: Practices and Prospects, WRI, Washington, DC, USA, 1995.

[8] I. Ndagi, F. D. Babalola, I. U. Mokwunye et al., "Potentials and challenges of kolanut production in Niger State, Nigeria," ISRN Agronomy, vol. 2012, Article ID 492394, 9 pages, 2012.

[9] D. Nyadanu, S. T. Lowor, A. Akpertey et al., "Genetic variability of bioactive compounds and selection for nutraceutical quality in kola [Cola nitida (Vent) Schott. and Endl.]," PLoS One, vol. 15, no. 12, p. e0242972, 2020.

[10] D. A. L. I. Brown and M. K. Afrifa, "Cola storage," Annual Report, pp. 47-50, Cocoa Research Institute, Accra, Ghana, 1972.

[11] K. Osei-Bonsu and M. K. Afrifa, "Kola storage experiment," Annual Report, pp. 44-45, Cocoa Research Institute, Accra, Ghana, 1976.

[12] K. Osei-Bonsu, M. K. Afrifa, and D. A. L. Brown, "Evaluation of different packaging materials for the storage of colanuts," in Proceedings of the 13th Biennial Conference, Legon, Ghana, August 1987. 
[13] E. Owusu-Manu and M. E. Bonku, "Estimation of pod/nut losses due to insect damage," Annual Report, pp. 127-130, Cocoa Research Institute, Accra, Ghana, 1994.

[14] Ministry of Food and Agriculture, Agriculture in Ghana: Facts and Figures 2013, Statistics, Research and Information Directorate, MOFA, Accra, Ghana, 2015.

[15] B. B. Babatunde and R. A. Hamzat, "Effects of feeding graded levels of kola nut husk meal on the performance of cockrels," Nigerian Journal of Animal Production, vol. 32, no. 1, pp. 61-66, 2005.

[16] G. B. Beattie, "Soft drink flavours: their history and characteristics I. cola for kola flavours," The Flavour Industry, vol. 1, no. 6, pp. 390-394, 1970.

[17] D. B. A. Ogutuga, "Chemical composition and potential commercial uses of kola nuts Cola nitida (Vent.) Schott \& Endlicher," Ghana Journal of Agricultural Science, vol. 8, pp. 121-125, 1975.

[18] M. A. O. Oladokun, "Objectives and achievements in kola propagation," in Proceedings of the Symposium Marking the 21st Anniversary of CRIN, Ibadan, Nigeria, December 1985.

[19] E. Abaka, Kola nut production in Ghana (Gold Coast and Asante), 1865-1920, Ph.D. Thesis, York University, Toronto, Canada, 2000.

[20] M. Asamoah, K. Osei-Bonsu, and O. Sarkodie, "A survey of raw processing methods for kolanuts," Journal of the Ghana Science Association, vol. 2, no. 1, pp. 105-108, 2000.

[21] S. T. Lowor, "Studies on the chemical composition and storage parameters of sun-dried kola nuts," African Journal of Agricultural Research, vol. 3, no. 2, pp. 130-133, 2008.

[22] E. U. Asogwa, A. H. Otuonye, F. C. Mokwunye, K. A. Oluyole, T. C. N. Ndubuaku, and E. O. Uwagboe, "Kola nut production, processing and marketing in the south-eastern states of Nigeria," African Journal of Plant Science, vol. 5, no. 10, pp. 547-551, 2011.

[23] E. Sanial and F. Ruf, "Is kola tree the enemy of cocoa? a critical analysis of agroforestry recommendations made to Ivorian cocoa farmers," Human Ecology, vol. 46, no. 2, pp. 159-170, 2018.

[24] O. Ekanade, "Spatio-temporal variations of soil properties under cocoa interplanted with kola in a part of the Nigerian cocoa belt," Agroforestry Systems, vol. 5, no. 4, pp. 419-428, 1987.

[25] M. A. O. Oladokun and N. E. Egbe, "Yields of cocoa/kola intercrops in Nigeria," Agroforestry Systems, vol. 10, no. 2, pp. 153-160, 1990.

[26] R. Osei and M. Ansong, "Drivers of mistletoe (Tapinanthus bangwensis) density in cocoa (Theobroma cacao) agroforests in Ghana," International Journal of Pest Management, pp. 1-8, 2020.

[27] E. Owusu-Manu and Y. Mama, Balanogastris Kolae Damage During Curing of Kola Nuts, pp. 166-168, Cocoa Research Institute, Accra, Ghana, 1995.

[28] S. A. Adenikinju, K. Badaru, and C. R. Obatolu, "Harvesting, processing and storage of cacao, kola, coffee, cashew and tea," in Progress in Tree Crop Research, pp. 42-52, Cocoa Research Institute of Nigeria, Ibadan, Nigeria, 1989.

[29] C. L. M. V. Eijnatten, Distribution of Various Cola Species and Location of Cultivated Kola, of Research Importance (A Review of Literature), Cocoa Research Institute of Nigeria, Moor Plantation, Ibadan, Nigeria, 1964.

[30] S. O. Ojo and O. O. Ehinmowo, "Economic analysis of kolanut production in Nigeria," Journal of Social Sciences, vol. 22, no. 1, pp. 1-5, 2010.
[31] C. S. Osalusi, "Price determinant of kolanut in selected markets in Ibadan, Oyo State, Nigeria," International Journal of Agricultural Research, Sustainability, and Food Sufficiency, vol. 6, no. 2, pp. 344-347, 2019. 